\title{
Food sovereignty: sustainable solution to world hunger and climate change
}

institucional.us.es/ambitos/

\section{Lourrene Maffra}

Universidad Federal de Amapá (Brasil)

Versión en Castellano: Soberanía alimentaria: solución sostenible al hambre mundial y al cambio climático.

The link between hunger and climate change is already known and is not new in the literature, especially if we take into account only the national level and trade related. The intense land use to produce just one cultivation, the burning and deforestation methods applied to clear the soil and to make the crops rotations, which damage the mineral resources and displace animals from their habitats, jointly with the intense use of pesticides and transgenic technology in the agriculture, such as in soy and corn cultures, are related to the increase of hunger in the world because hunger is not only about production, but also consumption (income of people and quality of food choices) and distribution (food waste and poor people access to food), and the

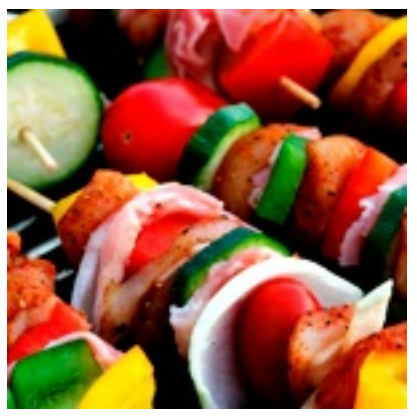
way the soil is managed is crucial for the production of nutritious quality food.

However, an underexplored approach has great potential to provide important elements in the search for a sustainable and lasting solution to those issues. This approach is the concept of food sovereignty. The concept of food sovereignty includes production and consumption in local level, but aiming the collective well-being, through using sustainable techniques to produce food (natural fertilizers, adequate planting and collection cycles for each type of food, no use of artificial pesticides and adequate soil management without deforesting, polluting or burning areas), prioritizing family farming and the supply of more nutritious and quality food. This concept addresses some possible solutions to two of the most bother issues in the present time in a multi-level analysis to counter economic and political marginalization. Food sovereignty practices would lead us to end, or at least reduce, the hunger situations and the problems related to climate changes as long as we improve our food systems to efficient, but also more human ones.

Keywords: food sovereignty, hunger, climate change, public policy.

Resumen: El vínculo entre el hambre y el cambio climático ya es conocido y no es nuevo en la literatura, especialmente si lo tenemos en cuenta solo a nivel nacional y el comercio relacionado. El uso intensivo de la tierra para producir un solo cultivo, los métodos de quema y deforestación aplicados para limpiar el suelo y hacer rotaciones de cultivos, que dañan los recursos minerales y desplazan animales de sus habitats, sumado al intenso uso de pesticidas y tecnología transgénica en la agricultura, como en los cultivos de soja y maíz, están relacionados con el aumento del hambre en el mundo, porque el hambre no es solo producción, sino también consumo (ingresos de las personas y calidad de la variedad de alimentos) y distribución (alimentos desperdiciados y acceso de la gente pobre a los alimentos), y la forma en que se maneja el suelo es crucial para la producción de alimentos nutritivos de calidad. Sin embargo, un enfoque poco explorado tiene un gran potencial para proporcionar elementos importantes en la búsqueda de una solución sostenible y duradera para esos problemas. Este enfoque está en el concepto de soberanía alimentaria. El concepto de soberanía alimentaria incluye la producción y el consumo a nivel local, pero teniendo como objetivo el bienestar colectivo, mediante el uso de técnicas sostenibles de producción de alimentos (fertilizantes naturales, ciclos adecuados de siembra y recolección para cada tipo de alimento, no usar pesticidas artificiales y un adecuado uso del suelo sin deforestación, contaminación o quema de áreas), priorizando la agricultura familiar y el suministro de comida más nutritiva y de mayor calidad. Este concepto aborda algunas posibles soluciones a dos de los problemas más problemáticos en el presente en un análisis a varios niveles para contrarrestar la marginación económica y política. Las prácticas de soberanía alimentaria nos conduciría a ponerle fin, o al menos reducir, las situaciones 
de hambre y los problemas relacionados con el cambio climático siempre y cuando mejoremos nuestros sistemas alimentarios para que sean más eficientes, pero también más humanos.

Palabras clave: soberanía alimentaria, hambre, cambio climático, política pública.

\section{Introduction}

The purpose of this article is present the currently debates around the food sovereignty concept and how those debates could clarify and provide more understandings and successful decisions to the climate change international agenda.

Since 90's, we have been discussing about all transformation that our planet has been suffered in the last five decades, with increase in temperatures, deforestation, water and air pollution, etc. The 90's, also known as "Conferences Decade" by the United Nations, was full of several international meetings and conventions about many subjects, especially those connect to development, social problems and environment.

Also in 90's, specifically in 1996, an international NGO, called La Vía Campesina, initiated the debates about family farming, rural development, gender and equality, fighting hunger and sustainability, and led the first discussions about the food sovereignty concept.

The concept of food sovereignty includes, among other things, locating production and consumption and working the land and using resources sustainably. That is that concept is not only about de quantities of food and their quality, but also who and where is producing and the access to then. Then, there is also important relationship with the environment, in an effort to preserve, but working with it, using in the best way the natural resources.

Therefore, our aim is discussing how the concept of food sovereignty address important features to the policy and decision makers to understand and create strategies to fighting efficiently the world hunger and climate change.

\section{Concepts discussions}

There is yet some unclear ways to think about complex and transnational themes, such as world hunger and climate change. Those themes are generally approached under a single way of understanding or with shallow connections between their causes and consequences. It's important to address several questions to reach a holistic view of those two big problems in the world and their possible solutions.

The concept of hunger that we analyze in this article is related to the FAO's (Food and Agriculture Organization) definition, which is "the distress associated with lack of food" [1], but also includes a definition for food deprivation, or undernourishment, as

the consumption of food that is not sufficient to provide the minimum amount of dietary energy that each individual requires to live a healthy and productive life, given his or her sex, age, stature and physical activity level. (FAO, 2016)

Hunger, in our description, refers to the conjugation of four components, child wasting, child stunting, child mortality and undernourishment, reflect deficiencies in calories as well as in micronutrients.

Figure 1: Prevalence of Undernourishment in the Population. 


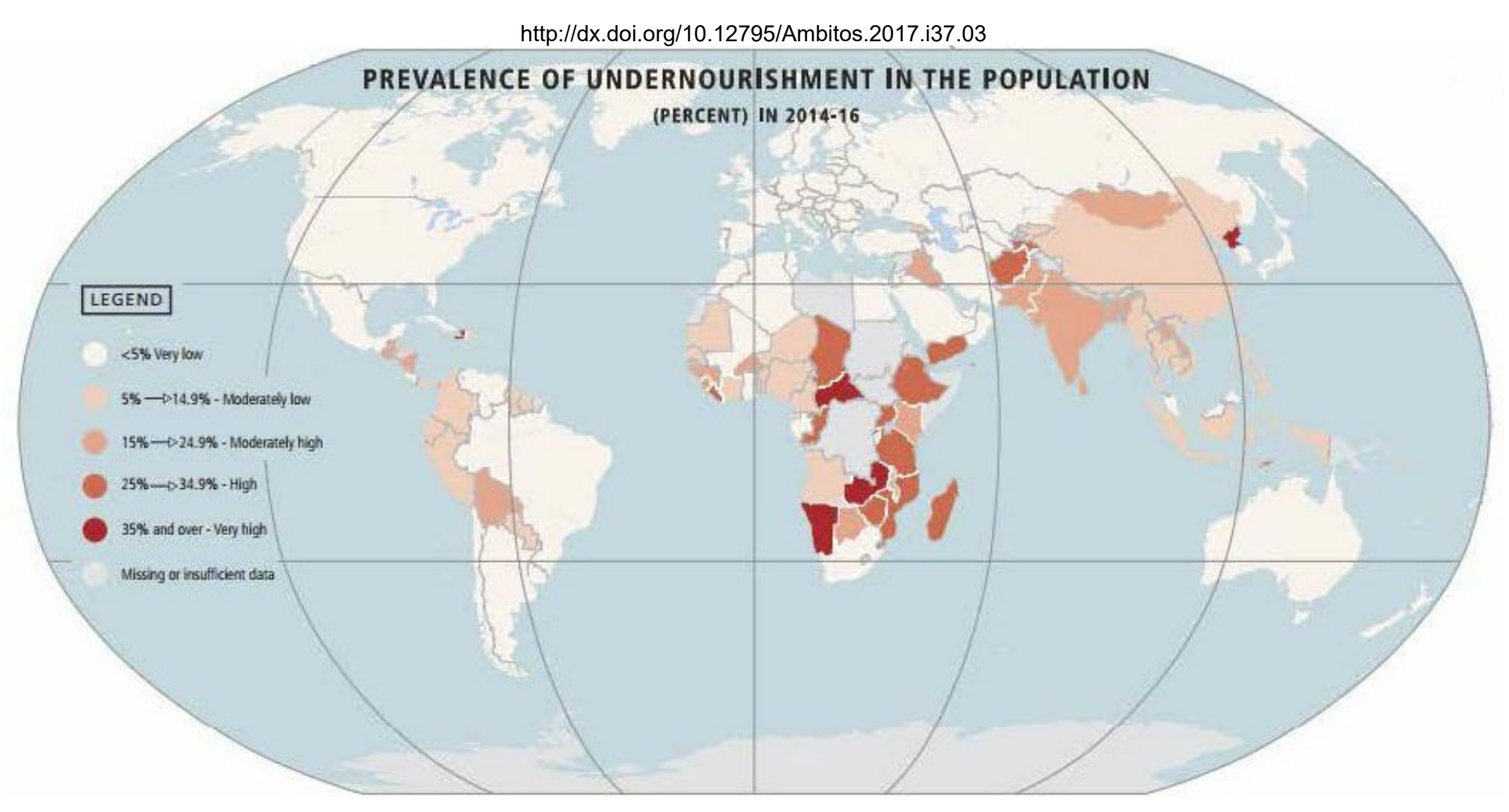

Source: FAO. World Food Map, 2015

According to the last World Hunger Map (FAO, 2015a), there are still 793 million famine people in the world, the majority is located in the sub-Saharan region and Central and Southeast Asia countries. The year 2015 is also relevant because it was the end of the Millennium Development Goals (MDG) monitoring and many studies and index were done to make the final assessment on how and what goals have been achieved, as well as which countries reach them. Seventy - three (73) of one hundred twenty-nine (129) countries have reached MDG number one target: Eradicate Extreme Poverty and Hunger.

Still according to World Hunger Map (FAO, 2015a),

In many countries that have failed to reach the international hunger targets, natural and human-induced disasters or political instability have resulted in protracted crises, with increased vulnerability and food insecurity among large segments of the population.

Related to hunger situation is important to highlight the stage which has been debated in many international organizations and agencies, that is food insecurity. In consonance with FAO, food insecurity occurs when these four components cannot be identified in proper ways: 1) The food is physically available; 2) The people has economic and physical access to food; 3) Sufficient energy and nutrient intake by individuals; and 4) Stability of the other three dimensions over time (which means that there is no interruption of the provision of these previous conditions). (FAO, 2008)

More precisely, food insecurity is defined as

A situation that exists when people lack secure access to sufficient amounts of safe and nutritious food for normal growth and development and an active and healthy life. It may be caused by the unavailability of food, insufficient purchasing power, inappropriate distribution or inadequate use of food at the household level. Food insecurity, poor conditions of health and sanitation and inappropriate care and feeding practices are the major causes of poor nutritional status. Food insecurity may be chronic, seasonal or transitory. (FAO, IFAD, and WFP, 2015, p.53)

Food insecurity is directly related to hunger. All hungry people are insecure food, but the opposite is not entirely true, because there are other causes for food insecurity, such as environmental conditions (droughts, heavy rains, pests), economic crisis, environmental disasters, etc.

There are other phenomena related to hunger, such as poverty and low productivity. They deepen the conditions 
of famine and deteriorate local and national food systems. The following figure shows a vicious cycle of the factors that cause hunger.

Figure 2: Vicious Cycle of Hunger Factors

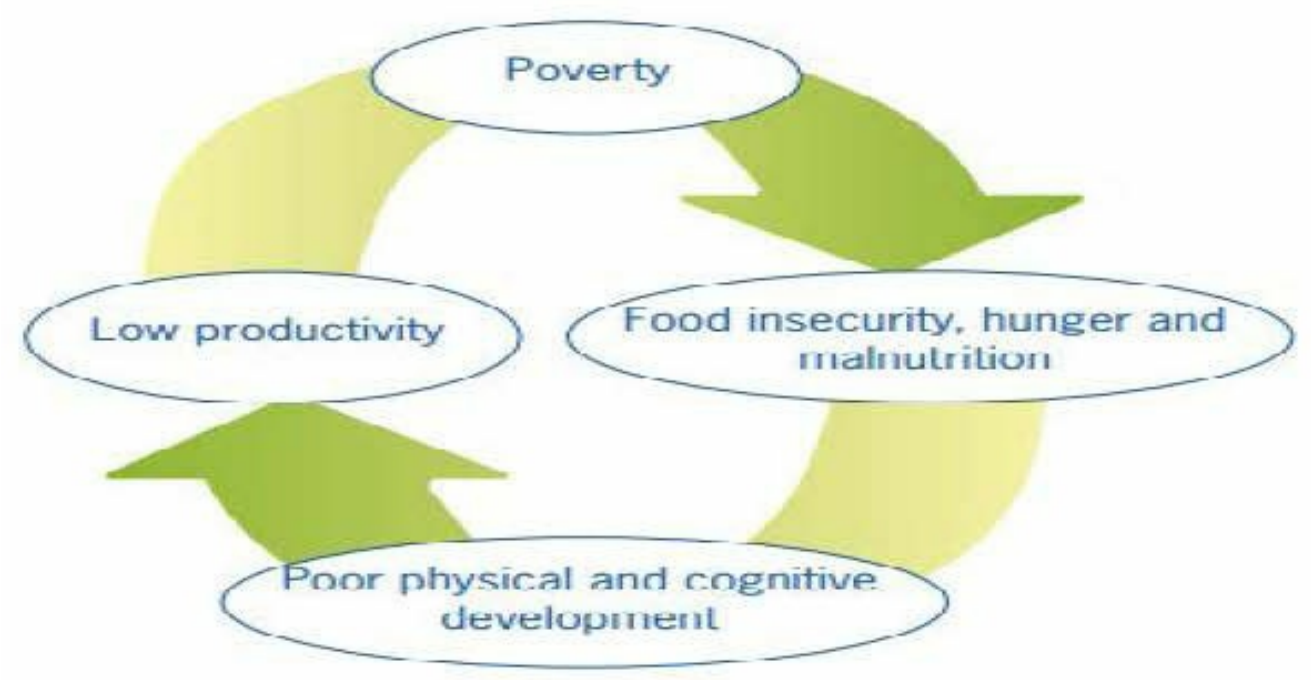

Source: FAO, http://www.fao.org/docrep/013/al936e/al936e00.pdf

The food insecurity's definition is also important to be analyzed because incorporates besides all aspects related to food production and consumption and income of the population, appropriate sanitary conditions are an important part because concern to the environment where people live.

Appropriate sanitary conditions provide for to the community clean water access, commonly used to prepare food and, even to drink to survive, the adequate sewerage management - that prevents soil contamination, and several kinds of diseases, such as cholera.

On that subject, the importance of adequate soil management is crucial to reach food security. First, due to intense pesticide and fertilizer's use, the soil today is no more so fertile as in the past, and the most crops withdraw all the basic nutrients of it, making it poorest and takes more time to recover itself to another crop season.

Another factor influences the food production and, consequently, food security is climate change. The world has seen an increase in the number and intensity of both floods and droughts, which can destroy crops and necessary infrastructure. Rising sea levels can render land unsuitable for growing crops, and glacial melt can affect water quality. Higher temperatures, along with too much or too little rainfall, can decrease both the quality and quantity of crops. [2]

Leandro Belini (2004) clarifies that both the market and the pattern of consumption are reflections of the development of the capitalist system, based on the search for the maximization of consumption and production. However, as a direct reflection of this systemic dynamics, the industrial society faced completely new conditions: "the anthropic action in the environment is changing the earth's climate" (BELINI, 2004, p.1).

Belini (2004) states that the current source of energy generation adopted by most states is based on the use of fossil fuels, such as coal, oil and natural gas, and these have contributed to the massive increase in emissions of greenhouse gases in the atmosphere, altering the natural balance of the planet and intensifying the phenomenon of global warming.

According to the National Institute of Space Research (INPE, 2016) - a Brazilian research institute, the greenhouse effect is a natural phenomenon that allows the existence of life on the Earth's surface, generated by the presence of gases in the atmosphere, especially carbon dioxide $\left(\mathrm{CO}_{2}\right)$.

The gases from this phenomenon constitute a natural barrier that prevents the emission of radiation from the 
earth's surface is sent back into space, thus causing an optimum temperature, but when the concentration of these gases in the atmosphere increases, the greenhouse effect becomes even more intense, and in this case, the warming of the lower atmosphere occurs, raising the average temperature of the Earth and causing the climate changes.

The intensification of the greenhouse effect due to the human action associated to its natural manifestation, which has consequently led to an environmental unbalance, has been characterized as one of the major geopolitical challenges already faced in the international level because of its magnitude with economic, social and environmental political effects (GALORO, 2004)

In this regard, the condition of global problem of this phenomenon assumes a very important role in the international agenda, demanding a great effort for an effective solution, paradigmatically changing the relation between man and the environment to which it belongs and / or a reformulation of the current model Which have proved to be incompatible with the proposals established by international agreements and treaties to solve these problems, such as the Kyoto Protocol (1998), for example. (GALORO, 2004).

Historically, the end of the 1980 s and early 1990 s is considered to be the period that most sheltered international discussions, forums, and conferences with the aim of addressing issues relating to the environment in general. At that time, the creation of the World Commission on Environment and Development, responsible for carrying out a comprehensive evaluation of environmental problems related to economic development.

Presided over by the then Norwegian Prime Minister Gro Harlem Brundtland, the Commission's work resulted in the publication in 1987 of a report entitled Our Common Future, also known as the Brundtland Report, which consolidated the concept of sustainable development, Conservationists capable of promoting development, without squandering the resources of the planet" (MENDONÇA, 2005), that is, a model of development that guarantees quality of life today, but does not destroy the resources needed by future generations.

The feasibility of this project depended on the inclusion of environmental policies recommended by the Commission in the process of economic decision-making. Among the recommendations, there were:

the reduction of the use of raw materials and energy, the use of renewable energy sources, limiting population growth, combating hunger, preserving ecosystems, ecologically balanced industrialization, meeting basic needs for all humanity, changing values and standards of Consumer society and the responsibility of the State to implement policies based on justice and social equity. (MENDONÇA, 2005)

In march of this currently year, the United Nations released un alert about what they called "The worst humanitarian crisis since 1945" [3] to talked about a severe hunger situations in some places in the world: Somalia, South Sudan, Yemen and Nigeria. The organization's chief of staff, Stephen O'Brien, said this is because more than 20 million people face or are at risk of starving. According to O'Brien, it would require an injection of $\$ 4.4$ billion by July to avoid a disaster.

For the UN, the hunger crisis is categorized by high rates of mortality, malnutrition and hunger. In the last 30 years, the institution has only identified the problem in about ten cases. The main causes of this recent crisis are impacts of conflicts and civil wars, high prices and extreme weather events such as prolonged droughts or excessive rainfall. In the Somalia's case, for example, the lack of food was also caused by the drought, caused by the climate phenomenon EI Nino - killed livestock and plantations, leaving 6.2 million in need of urgent help.

Thus, the link between the deepening of hunger situations in the world and the climate change is direct. In some parts of the world, there has been a greater incidence of extreme natural phenomena, such as heavy rains, floods, hurricanes and periodic droughts, causing a deterioration in soils, either by increased water infiltration or lack of water, or by the loss of nutrients. This deterioration leads producers to increase the use of pesticides and transgenic techniques (mostly in the soy and corn crops production) to resist pests, generating a chain that produce bad food, with low nutritional quality, and worsening the soil quality for the next crops season. 


\section{The construction of a sustainable solution: The Food Sovereignty debate}

Unlike the classical concept of sovereignty over territories and the utilization of power dynamically, the concept of food sovereignty is composed by the idea of the people's role, not only by the food theme itself, but also about the development of people with quality of life and decision-making power over their own lives.

The debate on the question of food sovereignty is considered recent, however, it is connected with other issues, also with the participation of local and national governments, non-governmental organizations and international organizations.

The traditional concept of sovereignty has an internal character and an external character. At the internal level (that is, within the territorial limits of the State) there is an agent who exercises power greater than all others, being the expression of the highest legal authority. For the rest of the states (that is, in the external domain), sovereignty acquires the meaning of independence to the extent that states want non-submission to foreign powers. (DALLARI, 2011).

The concept of food sovereignty, in turn, the discussions go beyond traditional concerns about the power to be exercised within certain territorial boundaries. This is because it is influenced by the process of globalization, in which there is the growing importance of non-state actors and individuals themselves in the International System. The discussions developed by the concept of Food Sovereignty will mainly deal with the power of individual decision about their own life and the right to the quality of life.

The historical point for the analysis of food sovereignty is the context of globalization since the 1970s. Some of the discussion topics about globalization and its impacts on agriculture include trade liberalization with changes in world trade standards of agricultural products; The elimination of subsidies to small farmers in the South as measures of "austerity" resulting from the neoliberal model; The market concentration by the global enterprises in the agricultural industry; New organizational technologies deployed by these corporations with processing and manufacturing for retail distribution, and how these technologies, when combined with economic power business, ultimately shape and restrict farmers' and the consumer practices and "choices". (Bernstein, 2013).

The creation of the concept of food sovereignty is attributed to the international movement of peasants, family farmers, fishermen, rural workers, foresters and indigenous groups: La Vía Campesina.

La Vía Campesina was formed in 1992 at a meeting of peasant leaders from Central America, North America and Europe in Nicaragua. In 1993, in Belgium, where it was its first conference, it was incorporated as a world organization and its objectives and strategies were outlined. (La Vía Campesina, 1992)

Among its strategies was participation in important international meetings such as the World Food Summit (WFS) in 1996 and 2002 and the World Social Forum held in Brazil in Porto Alegre in 2001. The positioning of the Via Campesina at these events already outlined what the future would be the formation of the concept of food sovereignty, giving an opinion on agrarian reform, agricultural production and trade and the right to food.

In order to develop a definition in a formal and democratic way, Via Campesina organized two international conferences that would have as its theme Food Sovereignty. The first was the World Forum on Food Sovereignty held in Havana, Cuba, in 2001 , attended by 400 delegates from organizations of peasant, indigenous, landless, fisher, small and medium-sized farmers, along with academics and researchers from 60 different countries. The second event was the World Forum for Food Sovereignty - Nyéléni in 2007 which was held in Mali with the participation of 600 representatives of the same types from the first conference organizations, but with the addition of rural workers, migrants, communities' forestry, consumers, environmental and urban movements in more than 80 countries.

The World Forum for Food Sovereignty clarified the objectives and actions of the movement and addressed seven thematic areas, namely trade policies and local markets; Knowledge and local technology; Access to and control over natural resources; The exchange of territories in all sectors; Response to conflicts and natural disasters; and migration, and production models. (Lee, 2007). In this way, was presented the demand for a radical change in the rules governing agriculture and food at the international level and the critique of the 
neoliberal economic model, which reduces the rural worker to give importance to tradable goods.

It is also important to examine the idea that food sovereignty has emerged as a reaction to the use of the term food security. According to the FAO's definition (Food and Agriculture Organization), "Food security exists when all people have at all times physical and economic access to sufficient safe and nutritious food to meet their food needs and food preferences for an active and healthy life. " (World Food Summit, 1996, quoted in FAO, 2008).

In the view of food sovereignty's advocates of this idea shows the importance of having a good and sufficient food, but without discussing the place that food comes, who produced and the conditions under which it is grown. Therefore, major food exporters have finally convinced poor countries to import their cheap food as a means to achieve food security, rather than encouraging them to produce their own food. This makes the increased dependence of these countries on the international market, which can contribute to food security worsen. (Pimbert, 2009).

What the concept of food sovereignty presupposes then goes beyond and requires agrarian reform in favor of small farmers and landless peasants, the reorganization of world food trade and encouraging local markets to create an egalitarian, just, sustainable food system and autonomous. Via Campesina (1996) considers that food sovereignty is a precondition for the existence of Food Security.

The discussions that emerged from the aforementioned conference were definitive for the formation of the concept of food sovereignty, hence defined as the right of peoples, communities and countries to establish their own agricultural policies, livestock, labor, fishing and food in order to be ecologically, socially, economically and culturally appropriate to their unique circumstances. This includes the true right to food and food production. (La Vía Campesina, 1996).

Food sovereignty provides a framework for the governance of agricultural and food policies that incorporates a wide range of issues such as agrarian reform, land control, local markets, biodiversity, autonomy, cooperation, debt, health, and others related to the ability to produce food locally.

Therefore, Food Sovereignty is the right of peoples to nutritious and culturally appropriate food produced through sustainable and healthy methods. It is your right to define your own food and agricultural policies and systems.

There are some strengths and critics in those discussions about the food sovereignty concept [4]. The strengths are about:

- Food sovereignty address root causes of economic marginalization of small farms.

- Food sovereignty is also about political marginalization.

- The concept of food sovereignty leads to the development of multi-level approaches to counter economic and political.

And the critics are:

- There is still a lack of clarity on practical implications and benefits of implementing food sovereignty as a development framework.

- The food sovereignty movement risks distancing itself from international policymaking when not considering potential benefits of agricultural trade liberalization and proposing to remove agriculture from WTO

The debate process to reach clear definition is still going on because it is a dynamic process, including the persuasion state authorities and community, besides the extensive discussions and forums in local, national and international level, that is, because of the peculiar nature of this concept of food sovereignty, which address the permanent dialogue with local producers and food related agents and vigilance in listening to their demands and submitting them to the government so that they can be transformed at some point into public policies aimed at improving the quality of food production and that consumers have access to food in an effective and fair price manner. 
Therefore, the implementation of the concept of food sovereignty in viable and effective public policies would result in, at least, three positive consequences for the local population: 1) more empowered individuals, especially women, with more quality food choices available; 2 ) low environmental impact in soil management and, consequently, more viable drinking water availability; 3 ) little or no release of pollutants into the water, soil and air.

The first possible positive consequence of the food sovereignty concretization is related a one voice more active of the individuals in the food system as consumers, mainly from feminine voice because, in general, women have an important role in acquisition of food for a family and, when they reach a higher food educational level (about nutrients, kind of foods, origins, logistics of distribution, local markets, prices), they probably will choice better. By choosing better, the first two links of the cycle of the food system (production, distribution and consumption) are under pressure to satisfy this kind of demand.

The second consequence is about the kind of production that is carried out due its requirement to work with the environment, in the more sustainable way possible. In other words, the is an obligation and a common sense of the producers to use techniques and methods to produce, collect, explore, fish and so on, that no harm the nature, either for the no use of pesticides, for example, or no use of burned method to clean an area in order to plant. This kind of production choice have a directly consequence in soil quality for other crops season, causing a positive domino of, with less harmful substances in soil, less or none of those substances harmful penetrate the soil water table and no contamination of the drinking water. Quality soil is the basis for successful agricultural systems and food security. It resists floods and drought, and its carbon stocks contribute to climate change mitigation.

The third, but probably not the final one, consequence of the implementation of the food sovereignty concept is relate to the second one above cited, but in an extended way. It is claimed that produce food often requires the utilization of innumerous of products in order to combat pests or resist to atypical season of heavy rain, storms or droughts, but when the producer does "work with the environment", for example: using crop rotation, diversification, consortia, soil treatment as a living organism and, consequently, its organic management through green manure, mulch and organic compost results in more soil fertility. All those examples also imply in the nonemission of harmful waste gases from the process of launching pesticides in the soil and the use of fires to prepare the soil for planting, as well as there is no contamination of rivers since there is no infiltration of pollutants.

Thus,

There is still progress to be made in ending world hunger, and focusing on sustainable soil management can help to feed more of the world's population. Governments need to recognize the issue of soil degradation and invest in appropriate land management projects. They also need to effectively regulate contaminants that impact soil quality, while focusing specifically on protecting organic, carbon-rich soils such as peatlands and permafrost. Systems and technologies that can produce more food using less soil will be especially important. Feeding the world's people in the face of climate change requires a close look at the most basic requirement of food production: quality soil. [5]

In other words, it is necessary to reaffirm the relevance of a good soil management for the solution search for the two issues approached in this text: world hunger and climate change. Both issues have in soil quality the cause and the consequence of a bad management of the natural resources. And, by an efficient and organic way soil management, we also can reach the food security condition and mitigate the climate change.

It is also important to moot, in short words, how those concepts and problems are shown in regular medias around the world. Generally, they are approached in more academic ways in forums, conferences and so forth. However, in recent years (notably since Tsunami phenomenon in 2011 in Japan), all the medias talk about the possible consequences of climate change, mainly to countries below sea level, which ones would be the first to disappear with the increase of sea level by the melting of polar ice caps - one of the main Earth's warming consequences.

Nevertheless, the food sovereignty concept is quite no discussed by the traditional medias. Indeed, all the 
debate about the food sovereignty has emerged from alternative and experiences based forums, with the greater participations of the ordinary people, would say, the marginalized workers from agriculture. A lot is said and report about hunger, poverty and underdevelopment, but too little about solutions to these problems that involve the affected people, the productions methods and the environment conservation in the same equation.

Therefore, we have a little participatory international media when it comes to issues reaching more poor countries (hunger, food insecurity) and long-term consequences of current problems (climate change).

\section{Conclusions}

The causes and consequences of hunger and climate change, as well as the connection between these two phenomena, were already largely approached. However, our aim in this text was to discuss those two issues through theoretical views, point out current debates and elucidate some solutions, more to alert than to deplete the questions about them.

The hunger, for one side, is a multifaceted problem, that presents any kind of distress in one, two or even in the three sides of the flow of production - distribution - consumption. The focus in this text was more in the first aspect of production because its link with the second issue approached here, climate change, is clearer than the others. However, due to food loss (which takes place in production, postharvest, processing stages and distribution) and food waste (happens at retail and consumption), we also face hunger situations and the worsening this condition.

The climate change, for the other side, is also a problem with several possibilities of approaches to mitigate it. It is an interdisciplinary issue and, because of that, requires an interdisciplinary way to face it. For climate change mitigation is important to discuss public policy with the aim to decrease the $\mathrm{CO}_{2}$ level in the atmosphere and other kind of pollutants, as well decrease phenomena related to it, such as use of fires to clear planting areas, intensive use of pesticides and pollution of rivers and air.

For both issues, we discussed here the construction of the food sovereignty concept and how this concept, if implemented as a public policy, for example, could help to find a final solution for world hunger and mitigate climate change. We analyzed from three consequences: individuals' empowerment, especially women, low impact in soil and decrease of pollutants release in soil, water and air.

Finally, we reaffirmed the necessity to look better and work better when concerns to soil management, because the soil can retain great carbon levels and help to feed the world population. And more participation and discussions in regular medias with the objective to bring more information and knowledge about international issues, which have real consequences in every country in the world.

\section{Bibliographic references}

Belini, L. (2004). Mudanças climáticas e Relações Internacionais. Accessed April 30, 2017. Available at http://www.anppas.org.br/encontro_anual/encontro2/GT/GT13/luciano_belini.pdf

Bernstein, H. (2013). Food Sovereignty: A skeptical view. Food Sovereignty: A Critical Dialogue. Conference Paper \#1. Acessed in May, 27, 2017. Available at https://www.tni.org/files/download/1_bernstein_2013.pdf

Dallari, D. A. (2011). Elementos de Teoria Geral do Estado. 30. Ed. São Paulo: Saraiva.

FAO (2008). Food Security Information for Action Practical Guides. Accessed in May 23. Available at http://www.fao.org/docrep/013/al936e/al936e00.pdf

(2015). Food Security Indicators (Updated May 27, 2015). Accessed in May 20, 2017. Available at http://faostat3.fao.org/download/D/*/E. 
. (2015a). The State of Food Insecurity in the World. Accessed May 24, 2017.

http://www.fao.org/docrep/013/al936e/al936e00.pdf

. (2015b). World Hunger Map. Accessed May 23, 2017. Available at https://www.wfp.org/content/hungermap-2015

FAO, IFAD, and WFP (2011). The State of Food Insecurity in the World 2011: How Does International Price Volatility Affect Domestic Economies and Food Security? Rome: FAO. Accessed May 23, 2017. Available at http://bit.ly/XTiINx.

. (2015) The State of Food Insecurity in the World 2015. Meeting the 2015 International Hunger Targets: Taking Stock of Uneven Progress. Rome: FAO. Accessed May 23, 2017. Available at http://www.fao.org/3/ai4646e.pdf.

Galoro, N. (2004). A biodiversidade no plano internacional: riscos e oportunidades. Accessed May 23, 2017. Available at: http://www.anppas.org.br/encontro_anual/encontro2/index.html\#13 INPE. 2016.

Hospes, O. (2008). Food Sovereignty. Strategy \& Policy Brief \#7, March.

INPE. 2016. O que é o efeito estufa? Instituto Nacional de Pesquisas Espaciais, Accessed May 23, 2017. Available at: http://www.inpe.br/acessoainformacao/node/487

La Vía Campesina (1992). Managua Declaration of La Vía Campesina. Accessed in April, 27, 2017. Available at https://viacampesina.org/en/index.php/our-conferences-mainmenu-28/1-mons-1993-mainmenu-47/907-

(1996). The right to produce and access to land. Declaration presented at World Food Summit in Rome. Accessed in April, 18, 2017. Available at http://www.voiceoftheturtle.org/library/1996\%20Declaration\%20of\%20Food\%20Sovereignty.pdf\&gt

Lee, R. (2007). Food Security and Food Sovereignty. Accessed April, 28, 201. Available at:

http://people.ku.edu/ anirtak/foodsov_vs_foodsec.pdf\&gt

Mendonça, C. (2005). Desenvolvimento sustentável (1): Como aliar meio ambiente e economia. Accessed April, 28, 2017. Available at http://educacao.uol.com.br/disciplinas/geografia/desenvolvimento-sustentavel-1-comoaliar-meio-ambiente-e-economia.htm

Pimbert, M. (2009). Towards Food Sovereignty. IIED, London. Accessed April, 30, 2017. Available at http://dlc.dlib.indiana.edu/dlc/bitstream/handle/10535/5851/14855IIED.pdf?sequence=1\&gt

[1] In estimating the prevalence of undernourishment (FAO, IFAD - International Fund for Agricultural Development -, and WFP - World Food Programme, 2015), FAO considers the composition of a population by age and sex, taking into account the range of physical activity levels of the population and the range of healthy body masses for attained height to calculate its average minimum energy requirement. This requirement varies by country-from about 1,650 to more than 1,900 kilocalories per person per day for developing countries in 2014-2016 (FAO, 2016)

[2] Jane Harkness, based in FAO (2015, at https://borgenproject.org/ensuring-food-security-sustainable-soilmanagement/ Accessed in 25/05/17.

[3] News available at http://www.bbc.com/portuguese/internacional-39243234, accessed in April, 30 th, 2017.

[4] Source: HOSPES, Otto. March - 2008. Food Sovereignty. Strategy \& Policy Brief \#7.

[5] Jane Harkness, based in FAO (2015, at https://borgenproject.org/ensuring-food-security-sustainable-soilmanagement/ Accessed in 25/05/17. 
- Recibido: 30 de mayo de 2017

- Aceptado: 21 de junio de 2017

Ámbitos. Revista Internacional de Comunicación, n.37, edición de verano, 2017. 